\begin{tabular}{ll} 
& \multicolumn{1}{c}{$\begin{array}{c}\text { Article History } \\
\text { Sahel J. Vet. Sci. Vol. 17, No. 3, pp. 1-5 (2020) }\end{array}$} \\
Copyright (C) 2020 Faculty of Veterinary Medicine, University of Maiduguri & $\begin{array}{l}\text { Received: } 04-2020 \\
\text { Revised: } \mathbf{1 8 - 0 6 - 2 0 2 0}\end{array}$ \\
All rights reserved & Accepted: 24-06-2020 \\
Published: $\mathbf{2 9 - 0 9 - 2 0 2 0}$
\end{tabular}

\title{
Effects of Aqueous Leaf Extract of Acalypha wilkesiana on some Serum Biochemical Profiles of Mice in Sub-Acute Toxicity Studies
}

\author{
${ }^{1 *}$ Madziga, H. A., ${ }^{1}$ Chiroma, M., ${ }^{2}$ Sanni, S., ${ }^{1}$ Sandabe, U. K. and ${ }^{3}$ Sodipo, O. A
}

${ }^{1}$ Department of Veterinary Physiology and Biochemistry, Faculty of Veterinary Medicine, University of Maiduguri
${ }^{2}$ Department of Veterinary Pharmacology and Toxicology, Faculty of Veterinary Medicine, University of Abuja
${ }^{3}$ Department of Clinical Pharmacology and Therapeutics, Faculty of Basic Clinical Sciences, College of Medical Sciences, University of
Maiduguri
${ }^{*}$ Author for Correspondence:hannamadziga@yahoo.com

\begin{abstract}
Acalypha wilkesiana has been used for various medicinal purposes such as in the treatment of hypertension, fungal and bacterial infections. In this study, the effects of prolonged oral administration of the aqueous leaf extract on some biochemical profiles of mice were evaluated. A total of 80 mice were allocated to 4 groups (A, B, C and D) comprising of 20 mice each. Mice in group A (control) were given $(1 \mathrm{~mL})$ of distilled water orally while $1 \mathrm{~mL}$ of the extract was given to the mice in groups $\mathrm{B}$, $\mathrm{C}$ and $\mathrm{D}$ daily at the concentrations of 800,1000 and $1200 \mathrm{mg} / \mathrm{kg}$, respectively. This was continued for three weeks and at the end of each week, 4 mice from each group were humanely sacrificed and sera from blood samples collected were used for determination of activities of biochemical parameters. The results showed that administration of the extract resulted in significantly ( $p<0.05$ ) lower concentrations of total protein and cholesterol in the treatment groups at the 3rd week of treatment when compared to control values. Glucose level was significantly $(\mathrm{p}>0.05)$ higher in the extract-treated groups by the $3 \mathrm{rd}$ week of treatment, while activities of AST, ALT and ALP were not significantly $(\mathrm{p}>0.05)$ altered by the extract. There were no significant $(\mathrm{p}>0.05)$ differences between the levels of calcium, total and conjugated bilirubin in treatment and control groups, while sodium concentration was significantly $(\mathrm{p}<0.05)$ higher at day 14 after withdrawal of treatment, compared to the control. This study suggests that the extract of Acalypha wilkesiana has a hyperglycaemic effect.
\end{abstract}

Keywords: Acalyphya wilkesiana, Aqueous Leaf Extract; Serum Biochemistry; Liver

\section{INTRODUCTION}

Acalypha wilkesiana Muell-Arg (copper leaf, fire dragon plant, beef steak plant, Jacob's coat, match-me-if-you-can and locally called Eela or jiwene jinwinini), is a plant from the family Euphorbiacaece. The genus Acalypha comprises of about 570 species (Riley, 1963), a large proportion of which are weeds while the others are ornamental plants. The plants are found all over the world especially in tropical Africa, America and Asia (Ogundaini, 2005).

Some of the species of Acalypha are well known in traditional medicine and a few have actually appeared inappeared in Africa and in the mascarene Islands (Seebaluck et al., 2015) Acalypha wilkesiana was reported to be used in the treatment of hypertension (Ikewuchi et al., 2008). The plant was found to have antibacterial and antifungal properties (Akinde, 1986; Alade and Irobi 1993; Adesina et al., 2000; Ogundaini, 2005), and was earlier reported to be used in treatment of gastrointestinal disorders and fungal infections such as Pityriasis versicolor, Impetigo contagious, Taenia versicolor and other similar skin infections which affect the back, chest and the axillae of many infants in Nigeria (Oliver, 1959).Due to the wide usage of Acalypha wilkesiana, this study was conducted to evaluate the effect of prolonged oral administration of its aqueous leaf extract on serum biochemical profiles in mice experimental model.

\section{MATERIALS AND METHODS}

\section{Collection, Identification and Processing of Plant}

Fresh leaves and stem of Acalypha wilkesiana were collected in the month of June from Maiduguri, Borno State, Nigeria. The plant was authenticated to be Acalypha wilkesiana from the Department of Forestry, at the University of Agriculture, Makurdi, Benue State. The leaves were dried under shade, crushed and made into powder using a mortar and pestle in the laboratory and then stored in a plastic container.

\section{Aqueous Extract Preparation}

Two hundred gram (200 g) of the dried powdered leaf material was placed into a round bottom flask and 1 liter of distilled water was added after which the mixture was placed on a hot plate and allowed to boil for $1 \mathrm{hr}$. It was then allowed to cool and then filtered using Whatman filter paper No. 1. The filtrate was then evaporated to dryness using hot air oven at $50{ }^{\circ} \mathrm{C}$ and, thereafter, stored at $4{ }^{\circ} \mathrm{C}$ until used. The extract 
was made into a concentration of $100 \mathrm{mg} / \mathrm{ml}$ and the yield was $22.85 \% \mathrm{~W} / \mathrm{w}$.

\section{Experimental Animals}

A total of 100 adult mice, weighing 15-25 g, procured from National Veterinary Research Institute Vom were used for the experiments. They were kept in plastic cages in the Veterinary Physiology, Pharmacology and Biochemistry Laboratory of the University of Maiduguri; they were given two weeks to acclimatize, before the commencement of the experiments. They were fed with growers' mash (Vital feeds ${ }^{\circledR}$ Nig. Ltd. Jos) and clean water was given ad libitum.

\section{Ethical Statements}

Ethical procedure according to Council for International Organisations of Medical Sciences and the International Council for Laboratory Animal Science (2012), were used.

\section{Sub-acute Toxicity Studies}

A total of 80 mice were used for the study. The experimental animals were caged into 4 groups (A, B, C and D), of 20 mice each. Group A served as the control and were administered 1 $\mathrm{mL}$ of distilled water only throughout the period of the study. Group B, C and D mice were orally administered, daily, $1 \mathrm{~mL}$ of the leaf extract at doses of 800,1000 and $1200 \mathrm{mg} / \mathrm{kg}$, respectively, for three weeks. At the end of each week, 4 mice were humanely sacrificed. Blood samples were collected from the jugular vein of the sacrificed mice and serum was obtained by centrifugation of the clotted blood and used for the biochemical assays.

\section{Determination of some Biochemical Parameters}

The sera obtained was used for analysis of activities of alanine aminotransferase, aspartate aminotransferase and alkaline phosphatase, and concentrations of total protein, total cholesterol, total bilirubin, conjugated bilirubin, glucose, calcium and sodium.

\section{Determination of Serum Enzyme Activities}

Alanine aminotransferase (ALT), aspartate amino transferase (AST) and alkaline phosphatase activities were assayed using commercial test kits (Randox Lab Ltd, Ardmore, U.K.) as described (Babson et al., 1966; Gueroui and Kechrid, 2016).

\section{Determination of Serum Bilirubin}

Serum total and conjugated bilirubin concentrations were deterimined using colorimetric method (Jendrassik and Grof; 1938; Gueroui and Kechrid, 2016) with commercial test kit (Randox, Lab Ltd. Armore, U.K.).

\section{Determination of Serum Total Protein}

The serum total protein was determined spectrometrically (Peter et al., 1982).

\section{Determination of Cholesterol}

The serum cholesterol was determined as described by Allain et al. (1974) using the commercial test kit (Randox Lab Ltd, Ardmore, U.K.).

\section{Determination of Blood Glucose}

Immediately on collection, a drop of the fresh whole blood was placed on the sample-spot of glucose test strips. The stripe was placed in one-touch 11 glucose meter (Astoor and Kings, 1954) and results obtained were recorded.

\section{Statistical Analyses}

All values were expressed as Mean \pm Standard (S.D). Analysis of variance (ANOVA) was used to analyse the extent of variation among groups and $p$ value equal to or less than 0.05 ( $\mathrm{p} \leq 0.05)$ were considered significant, the computer statistical software GraphPad Instat ${ }^{\circledR}$ (2003) was used to analyse the data.

\section{RESULTS}

\section{Effects of the Leaf Extract Administration on Biochemical Profiles}

The effect of sub-acute oral administration of the aqueous extract of $A$. wilkesiana leaves on blood glucose and serum concentrations of total bilirubin, conjugated bilirubin, protein and cholesterol on treated mice is shown in Table 1 . The glucose values of the treated mice indicated a significant $(\mathrm{p}<$ 0.05 ) increase only at the third week of treatment in group (B and C) and first week of withdrawal with no significant changes in the first two weeks of treatment and second week of withdrawal when compared to the control.

The aqueous leaf extract administration induced no significant $(p>0.05)$ changes in total bilirubin and conjugated bilirubin values (group B, C and D) when compared to control. The total protein values of the leaf extract-treated groups $C$ and D significantly $(p<0.05)$ decreased at first and second week of treatment for the respective doses of $1000 \mathrm{mg} / \mathrm{kg}$ and $1200 \mathrm{mg} / \mathrm{kg}$, while a significant increase in this parameter occurred in group B leaf extract-treated mice with the dose of $800 \mathrm{mg} / \mathrm{kg}$. There were no significant $(p>0.05)$ changes in the total protein values of leaf extract-treated groups at third week of treatment and at the withdrawal periods, when compared to the control group.

The total cholesterol values of the leaf extract-treated mice significantly $(p<0.05)$ decreased at the third week of treatment, with no significant $(\mathrm{p}>0.05)$ changes at week 1 and 2 of treatment, and two weeks of withdrawal compared with the control.

\section{Liver Enzymes (AST, ALT, and ALP)}

Results in Table 2 indicated that the liver enzymes (AST, ALT and ALP) based on the treatment using the extract, showed no significant $(p>0.05)$ decrease. Similarly, days after extract withdrawal showed no significant ( $p>0.05$ ) changes, but at day 7 of extract withdrawal of AST indicated a significant $(\mathrm{p}<0.05)$ increase when compared to the control.

\section{DISCUSSION}

The finding that administration of the aqueous leaf extract did not significantly $(\mathrm{p}>0.05)$ affect the serum enzyme levels (ALT and ALP) in the leaf extract-treated mice suggests that it had low hepatic toxicity. The observed increase in serum 
AST activity in group B mice treated with $1000 \mathrm{mg} / \mathrm{kg}$ leaf extract at day 7 of extract withdrawal when compared to the control group in absence of such changes in ALT and ALP activities may indicate the source of this change was extrahepatic, perhaps skeletal and cardiac muscles, which were reported to contain the enzyme (Coles, 1974; Mayne, 1998; Gueroui and Kechrid, 2016). The absence of changes in serum ALT and ALP activities may also be an indication that mouse liver does not contain significant levels of the enzymes. For example, it was reported that liver of ruminants does not contain significant concentration of ALT (Coles, 1974). Liver enzymes are known to be liberated into the blood whenever liver cells are damaged and enzymes activity in the plasma is, thus, increased (Edwards et al., 1995).
An elevation in the serum activity of AST is known to occur in association with liver diseases in a variety of animal species and it is of diagnostic importance in the assessment of the level of liver cell damage only when no disease exists in other tissues, such as the skeletal and cardiac muscles, in which it is found in high concentration (Coles, 1974). The elevation of AST activity is suggestive of damage to the cytoplasmic and or mitochondrial membranes of liver or the skeletal and cardiac muscles resulting to altered membrane permeability and subsequent escape of the enzyme into interstices and eventually the plasma (Coles, 1974; Mayne, 1998; Gueroui and Kechrid, 2016).

Table 1: Effects of Sub-acute Oral Administration of Aqueous Extract of Acalypha wilkesiana Leaves on some Biochemical Parameters

\begin{tabular}{|c|c|c|c|c|c|c|}
\hline \multirow{2}{*}{\multicolumn{2}{|c|}{$\begin{array}{l} \\
\text { Extract Treatment } \\
\text { Dose (mg/kg) }\end{array}$}} & \multicolumn{3}{|c|}{ Treatment Days } & \multicolumn{2}{|c|}{$\begin{array}{l}\text { Days Post Treatment } \\
\text { (withdrawal) }\end{array}$} \\
\hline & & 7 & 14 & 21 & 7 & 14 \\
\hline \multirow{4}{*}{$\begin{array}{l}\text { Glucose } \\
(\mathrm{mg} / \mathrm{dl})\end{array}$} & Control (Distilled water) & $130.00 \pm 21.51^{\mathrm{a}}$ & $117.40 \pm 29.27^{\mathrm{a}}$ & $110.60 \pm 17.56^{\mathrm{a}}$ & $119.40 \pm 31.21^{\mathrm{a}}$ & $155.40 \pm 37.37^{\mathrm{a}}$ \\
\hline & $800 \mathrm{mg} / \mathrm{kg}$ & $110.20 \pm 24.79^{\mathrm{a}}$ & $103.60 \pm 13.43^{\mathrm{a}}$ & $124.20 \pm 19.97^{b}$ & $147.80 \pm 31.26^{\mathrm{a}}$ & $139.60 \pm 26.76^{\mathrm{a}}$ \\
\hline & $1000 \mathrm{mg} / \mathrm{kg}$ & $123.20 \pm 11.08^{\mathrm{a}}$ & $108.20 \pm 12.28^{\mathrm{a}}$ & $149.40 \pm 25.19^{b}$ & $124.20 \pm 17.59^{\mathrm{a}}$ & $135.00 \pm 40.84^{\mathrm{a}}$ \\
\hline & $1200 \mathrm{mg} / \mathrm{kg}$ & $103.60 \pm 19.53^{\mathrm{a}}$ & $114.20 \pm 19.69^{a}$ & $118.00 \pm 18.89^{b}$ & $132.20 \pm 17.89^{\mathrm{a}}$ & $129.60 \pm 45.37^{\mathrm{a}}$ \\
\hline \multirow{4}{*}{$\begin{array}{l}\text { Total } \\
\text { Bilirubin } \\
(\mu \mathrm{mol} / \mathrm{L})\end{array}$} & Control (Distilled water) & $3.60 \pm 1.14^{\mathrm{a}}$ & $3.20 \pm 0.84^{\mathrm{a}}$ & $7.60 \pm 1.34^{\mathrm{a}}$ & $8.40 \pm 0.89^{\mathrm{a}}$ & $7.40 \pm 1.67^{\mathrm{a}}$ \\
\hline & $800 \mathrm{mg} / \mathrm{kg}$ & $3.40 \pm 0.55^{\mathrm{a}}$ & $3.20 \pm 1.30^{\mathrm{a}}$ & $6.60 \pm 1.67^{\mathrm{a}}$ & $6.80 \pm 2.28^{\mathrm{a}}$ & $6.80 \pm 2.28^{\mathrm{a}}$ \\
\hline & $1000 \mathrm{mg} / \mathrm{kg}$ & $4.20 \pm 2.95^{\mathrm{a}}$ & $3.40 \pm 1.14^{\mathrm{a}}$ & $7.80 \pm 1.30^{\mathrm{a}}$ & $8.20 \pm 1.30^{\mathrm{a}}$ & $8.00 \pm 1.00^{\mathrm{a}}$ \\
\hline & $1200 \mathrm{mg} / \mathrm{kg}$ & $2.40 \pm 0.55^{\mathrm{a}}$ & $3.00 \pm 0.71^{\mathrm{a}}$ & $6.20 \pm 1.92^{\mathrm{a}}$ & $7.00 \pm 0.71^{\mathrm{a}}$ & $7.60 \pm 1.34^{\mathrm{a}}$ \\
\hline \multirow{4}{*}{$\begin{array}{l}\text { Conjugated } \\
\text { bilirubin } \\
(\mu \mathrm{mol} / \mathrm{L})\end{array}$} & Control (Distilled water) & $6.60 \pm 1.34^{\mathrm{a}}$ & $6.60 \pm 1.52^{\mathrm{a}}$ & $4.00 \pm 1.00^{\mathrm{a}}$ & $3.80 \pm 0.84^{\mathrm{a}}$ & $3.80 \pm 0.84^{\mathrm{a}}$ \\
\hline & $800 \mathrm{mg} / \mathrm{kg}$ & $7.40 \pm 1.14^{\mathrm{a}}$ & $6.20 \pm 1.30^{\mathrm{a}}$ & $2.80 \pm 0.84^{\mathrm{a}}$ & $3.20 \pm 1.30^{\mathrm{a}}$ & $3.00 \pm 1.00^{\mathrm{a}}$ \\
\hline & $1000 \mathrm{mg} / \mathrm{kg}$ & $6.60 \pm 2.30^{\mathrm{a}}$ & $6.20 \pm 1.92^{\mathrm{a}}$ & $3.60 \pm 1.14^{\mathrm{a}}$ & $3.60 \pm 0.89^{\mathrm{a}}$ & $3.80 \pm 0.84^{\mathrm{a}}$ \\
\hline & $1200 \mathrm{mg} / \mathrm{kg}$ & $3.60 \pm 1.14^{\mathrm{a}}$ & $6.20 \pm 1.30^{\mathrm{a}}$ & $2.60 \pm 0.89^{\mathrm{a}}$ & $3.80 \pm 0.45^{\mathrm{a}}$ & $3.60 \pm 0.55^{\mathrm{a}}$ \\
\hline \multirow{4}{*}{$\begin{array}{l}\text { Total } \\
\text { Protein } \\
\text { (g/L) }\end{array}$} & Control (Distilled water) & $70.40 \pm 9.66^{\mathrm{a}}$ & $69.20 \pm 9.01^{\mathrm{a}}$ & $73.60 \pm 7.64^{\mathrm{a}}$ & $70.40 \pm 1.14^{\mathrm{a}}$ & $79.40 \pm 1.67^{\mathrm{a}}$ \\
\hline & $800 \mathrm{mg} / \mathrm{kg}$ & $82.40 \pm 5.89^{\mathrm{a}}$ & $81.80 \pm 5.12^{\mathrm{a}}$ & $72.60 \pm 7.19^{\mathrm{a}}$ & $70.80 \pm 6.09^{\mathrm{a}}$ & $78.60 \pm 7.40^{\mathrm{a}}$ \\
\hline & $1000 \mathrm{mg} / \mathrm{kg}$ & $63.80 \pm 12.11^{\mathrm{b}}$ & $65.20 \pm 10.62^{b}$ & $79.00 \pm 2.45^{\mathrm{a}}$ & $75.60 \pm 3.65^{\mathrm{a}}$ & $68.00 \pm 4.85^{\mathrm{a}}$ \\
\hline & $1200 \mathrm{mg} / \mathrm{kg}$ & $66.00 \pm 6.32^{b}$ & $67.40 \pm 5.13^{b}$ & $72.60 \pm 7.44^{\mathrm{a}}$ & $68.80 \pm 4.38^{\mathrm{a}}$ & $72.60 \pm 5.59^{\mathrm{a}}$ \\
\hline \multirow{4}{*}{$\begin{array}{l}\text { Total } \\
\text { cholesterol } \\
(\mathrm{mg} / \mathrm{L})\end{array}$} & Control (Distilled water) & $4.34 \pm 0.94^{\mathrm{a}}$ & $5.16 \pm 1.71^{\mathrm{a}}$ & $5.96 \pm 2.27^{\mathrm{a}}$ & $6.18 \pm 4.55^{\mathrm{a}}$ & $5.14 \pm 2.25^{\mathrm{a}}$ \\
\hline & $800 \mathrm{mg} / \mathrm{kg}$ & $5.70 \pm 4.15^{\mathrm{a}}$ & $5.04 \pm 0.84^{\mathrm{a}}$ & $3.80 \pm 1.29^{\mathrm{b}}$ & $2.90 \pm 0.43^{\mathrm{a}}$ & $4.90 \pm 2.26^{\mathrm{a}}$ \\
\hline & $1000 \mathrm{mg} / \mathrm{kg}$ & $5.00 \pm 1.84^{\mathrm{a}}$ & $5.36 \pm 1.61^{\mathrm{a}}$ & $3.10 \pm 1.23^{\mathrm{b}}$ & $4.80 \pm 2.38^{\mathrm{a}}$ & $2.50 \pm 0.95^{\mathrm{a}}$ \\
\hline & $1200 \mathrm{mg} / \mathrm{kg}$ & $4.70 \pm 1.01^{\mathrm{a}}$ & $4.22 \pm 1.08^{\mathrm{a}}$ & $3.00 \pm 0.99^{\mathrm{b}}$ & $3.10 \pm 0.88^{\mathrm{a}}$ & $3.30 \pm 0.57^{\mathrm{a}}$ \\
\hline
\end{tabular}

$\overline{\mathrm{a}, \mathrm{b}}$, means with different superscript across the rows are significantly $(\mathrm{P}<0.05)$ different $(\mathrm{n}=5)$ 
Table 2: Effects of Sub-acute Oral Administration of Aqueous Extract of Acalypha wilkesiana Leaves on Liver Enzymes in Mice

\begin{tabular}{|c|c|c|c|c|c|c|}
\hline \multirow[b]{2}{*}{ Parameters } & \multicolumn{2}{|l|}{$\begin{array}{l}\text { Extract Treatment } \\
\text { Dose(mg/kg) }\end{array}$} & \multicolumn{2}{|l|}{ Treatment Days } & \multicolumn{2}{|c|}{ Days Post Treatment (withdrawal) } \\
\hline & \multirow[b]{2}{*}{ Control (Distilled water) } & 7 & 14 & 21 & 7 & 14 \\
\hline & & $231.20 \pm 89.04^{\mathrm{a}}$ & $149.80 \pm 37.98^{\mathrm{a}}$ & $175.20 \pm 53.92^{\mathrm{a}}$ & $97.80 \pm 8.41^{\mathrm{a}}$ & $161.80 \pm 67.84^{\mathrm{a}}$ \\
\hline Aspaartate & 800 & $186.20 \pm 122.59^{\mathrm{a}}$ & $154.00 \pm 33.71^{\mathrm{a}}$ & $140.40 \pm 54.97^{\mathrm{a}}$ & $98.20 \pm 7.92^{b}$ & $154.40 \pm 56.59^{\mathrm{a}}$ \\
\hline Aminotransferase & 1000 & $153.00 \pm 46.32^{\mathrm{a}}$ & $145.60 \pm 43.98^{\mathrm{a}}$ & $115.60 \pm 39.23^{\mathrm{a}}$ & $183.80 \pm 80.75^{\mathrm{c}}$ & $115.40 \pm 48.12^{\mathrm{a}}$ \\
\hline \multirow[t]{2}{*}{$(\mathrm{AST})$} & 1200 & $205.60 \pm 15.42^{\mathrm{a}}$ & $114.60 \pm 34.14^{\mathrm{a}}$ & $109.80 \pm 12.11^{\mathrm{a}}$ & $102.40 \pm 7.50^{\mathrm{a}}$ & $101.00 \pm 9.79^{\mathrm{a}}$ \\
\hline & Control (Distilled water) & $81.00 \pm 35.62^{\mathrm{a}}$ & $51.80 \pm 10.83^{\mathrm{a}}$ & $36.80 \pm 16.92^{\mathrm{a}}$ & $29.20 \pm 4.87^{\mathrm{a}}$ & $42.20 \pm 20.13^{\mathrm{a}}$ \\
\hline Alanine & 800 & $54.80 \pm 18.09^{\mathrm{a}}$ & $42.40 \pm 10.36^{\mathrm{a}}$ & $32.20 \pm 11.26^{\mathrm{a}}$ & $31.20 \pm 3.37^{\mathrm{a}}$ & $35.20 \pm 14.29^{\mathrm{a}}$ \\
\hline Aminotransferase & 1000 & $70.00 \pm 17.19^{\mathrm{a}}$ & $45.60 \pm 14.36^{\mathrm{a}}$ & $22.20 \pm 6.91^{\mathrm{a}}$ & $38.40 \pm 25.66^{\mathrm{a}}$ & $20.60 \pm 4.04^{\mathrm{a}}$ \\
\hline \multirow[t]{2}{*}{$(\mathrm{ALT})$} & 1200 & $67.60 \pm 28.13^{\mathrm{a}}$ & $34.80 \pm 14.94^{\mathrm{a}}$ & $19.60 \pm 5.03^{\mathrm{a}}$ & $23.80 \pm 8.14^{\mathrm{a}}$ & $23.60 \pm 6.35^{\mathrm{a}}$ \\
\hline & Control (Distilled water) & $147.80 \pm 75.72^{\mathrm{a}}$ & $91.60 \pm 13.96^{\mathrm{a}}$ & $84.60 \pm 31.18^{\mathrm{a}}$ & $74.20 \pm 33.97^{\mathrm{a}}$ & $54.20 \pm 10.52^{\mathrm{a}}$ \\
\hline Alkaline & 800 & $119.40 \pm 46.66^{\mathrm{a}}$ & $100.40 \pm 7.37^{\mathrm{a}}$ & $84.20 \pm 39.46^{\mathrm{a}}$ & $102.20 \pm 16.15^{\mathrm{a}}$ & $72.60 \pm 27.36^{\mathrm{a}}$ \\
\hline \multirow[t]{2}{*}{ Phosphatase (ALP) } & 1000 & $126.00 \pm 28.22^{\mathrm{a}}$ & $84.40 \pm 22.73^{\mathrm{a}}$ & $85.60 \pm 31.42^{\mathrm{a}}$ & $97.60 \pm 30.44^{\mathrm{a}}$ & $58.80 \pm 35.46^{\mathrm{a}}$ \\
\hline & 1200 & $126.20 \pm 35.56^{\mathrm{a}}$ & $80.40 \pm 31.29^{\mathrm{a}}$ & $73.40 \pm 24.35^{\mathrm{a}}$ & $66.40 \pm 25.13^{\mathrm{a}}$ & $45.60 \pm 13.76^{\mathrm{a}}$ \\
\hline
\end{tabular}

$\overline{a, b, c}$ means with different superscript across the rows are significantly $(\mathrm{p}<0.05)$ different $(\mathrm{n}=5)$.

However, in acute injury to the liver, as in viral hepatitis, the level of the ALT and AST may be used as a general measure of the degree of liver inflammation or damage. In chronic liver disease, this is not the case, for these enzymes may be entirely within the normal range, even in the presence of cirrhosis (scarring of the liver) (Anon, 2010). ALT is the more liver specific enzyme and therefore generally more sensitive to changes in activity levels than AST (Sodipo et al., 2009).

There was no significant $(\mathrm{p}>0.05)$ decrease in total bilirubin and conjugated bilirubin. Treatment with the extract of $A$. wilkesiana leaves indicated a significant $(\mathrm{p}<0.05)$ decrease in total protein and cholesterol level in treated mice when compared to the control. When the levels of serum cholesterol are lowered by diet or drugs, the rate of progression of atherosclerotic disease is slowed, some atherosclerotic plaques regress and the risk of cardiovascular events is reduced (Gotto, 1997). Glucose level in this study was observed to significantly $(\mathrm{p}<0.05)$ increase from 110.60 \pm 17.56 to $124.20 \pm 19.97,149.40 \pm 25.19$ and $118.00 \pm 18.89$. This is probably an indication that the extract has the ability to cause hyperglycaemia.

\section{Conclusion}

The liver enzymes were not affected except on day 7 postwithdrawal which indicated a decrease in AST with 800 $\mathrm{mg} / \mathrm{kg}$ which may be an indication of degenerative changes in the liver one week later and at $1000 \mathrm{mg} / \mathrm{kg}$ there was increase in AST which may also be a delay in the body response to infection. Protein and cholesterol show decrease indicating that the extract had a hyperglycaemic effect when taken in lower dosage and as a fat reducing agent. Calcium and Sodium levels were not affected during the treatment. Body weight was also not affected which may be why there was no increase in the cholesterol level.

\section{Acknowledgement}

The authors gratefully acknowledge the technical assistance of Bitrus Wampana of Veterinary Physiology, Pharmacology and Biochemistry, Mal Isa Gulani of Veterinary Medicine Department, Faculty of Veterinary Medicine. University of Maiduguri, and Mr. Fine Akawo of Department of Applied Chemistry, University of Maiduguri.

\section{Conflict of Interest}

The authors declare that they do not have any conflict of interest.

\section{Author's Contribution}

Project design; MHA, SS. and SUK. Original draft of manuscript; MHA. and SUK. Review and editing of manuscript MHA and CM. Interpretation of result; MHA, CM, SOA. and SUK. All authors read and approved the final manuscript.

\section{REFERENCES}

Adesina, S.K., O. Idowu, A.O. Ogundaini, H. Oladimeji, T.A. Olugbade, G.O. Onawunmi and M. Pais, (2000). Antimicrobial constituents of the leaves of Acalypha wilkesiana and Acalypha hispida. Phytotheraphy Res. 14: 371-372

Akinde B.E. (1986). Phytochemical and Microbiological Evaluation of the oils from the leaves of Acalypha wilkesiana. In: (A Sofowara,ed) The State of Medicinal Plant Research in Nigeria University of Ibadan Press, Nigeria, Pp. 362-363.

Alade, P.I., and O.N. Irobi, (1993). Antimicrobial activities of crude leaf extracts of Acalypha wilkesiana. J. Ethropharmocol. 39: 171-174

Allain, C. C., Poon, L. S. and Chan, C. S. G (1974). Enzymatic determination of total serum cholesterol. Clin. Chem. 20: 470 . 
Anon, (2010). http://clk.atdmt.com/go/243833028/direct; ai.172623908;ct,1/o1/.7 Acessed date 20/8/2010.

Astoor, A. M. and Kings, E. J. (1954). Estimation of blood glucose. J. Biochem. 56- 59.

Babson, L. A., Greeley, L. J., Coleman, C. M. and Phillips, G. D. (1966). In vitro determination of alkaline phosphatase in serum or plasma. Clin. Chem. 12: 482-490

Coles, E.H. (1974). Veterinary Clinical Pathology $2^{\text {nd }}$ Edition W.B. Saunder Company, Philadelphia, London, Toronto Pp. 190-271

CIOMS and ICLAS (2012). Council for International Organisations of Medical Sciences and the International Council for Laboratory Animal Science. International Guiding Principles for Biomedical Research Involving Animal, December 2012.

Edwards, C. R. W., Bouchier, I. A. D, Haslet, C. and Chilve rs, E.R. (1995). Davidson's Principles and Practice of Medicine, $17^{\text {th }}$ edn. Churchill living stone, $\mathrm{Pp}$ 490.

Gotto, A.M. (1997). Cholesterol management in theory and practice Circulation, 96: 4424-4425

Gueroui, M. and Kechrid, Z.(2016). Evaluation of some biochemical parameters and brain oxidative stress in experimental rats exposed chronically to silver nitrate and the protective role of vitamin $\mathrm{E}$ and selenium. Toxicol. Res. 32(4) 301-309
Ikewuchi, J, C. A.,Yovwe, A.U. E. and Osas, O. S. (2008). Effects fo Acalypha wilkesiana Muell Arg on Plasma sodium and potassium concentration of normal rabbits. Pak. J. Nutri.7 (1) 130-132

Jendrasik, L. and Grof, P. (1938). Calorimetric method for the deermination of total bilirubin, Biochem 2: 297:

Mayne; P. D. (1998). Clinical Chemistry. Diagnosis and Tretment $6^{\text {th }}$ ed. London: Arnold International;119204.

Ogundaini, A.O. (2005) From Green into Medicine: Taking a lead from Nature. An inaugural lecture series 176, delivered at Oduduwa Hall, M. Obafemi Awololwo University, Ile Ife, Nigeria p. 12-15

Oliver, B. (1959) Medicinal Plants in Nigeria, Nigerian College of Arts, Science and Technology, Ibadan p. 4

Riley, H. P. (1963). Families of Flowering Plants of Southern Africa, University of Kenturky Press, USA, Pp. 73.

Seebaluck, R., Gurib-Fakim, A., \& Mahomoodally, F. (2015). Medicinal plants from the genus Acalypha (Euphorbiaceae)-A review of their ethnopharmacology and phytochemistry. In J. Ethnopharmacol. 15: 159; 137-157.

Sodipo,O.A., Abdulrahman F.I., Sandabe U.K and Akinniyi F.I (2009). Effect of Solanum macrocarpum Linn. on biochemical liver function in diet-induced hypercholesterolaemic rats. Nig. Vet. J. 30 (1): $1-8$. 